POLICY BRIEFING SERIES

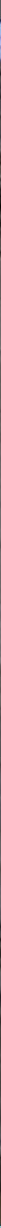

The New Constitutional Role

of the Judiciary

Jo Murkens and Roger Masterman 


\section{The New Constitutional Role of the Judiciary}

Over the last few decades, the UK has experienced a profound - if quiet - constitutional transformation. The judicial reception of EU law, for instance, has been described as 'one of the most fundamental realignments of the constitutional order since the end of the seventeenth century'. But these developments have hardly been appreciated within broader public debates, which remain rooted in/anchored to notions of parliamentary sovereignty.

$\mathrm{n}$ this paper, we describe the broad contours of constitutional change in the UK over the last decades. We also ask the question, what can and should courts do when faced with 'unconstitutional' legislation? We present the case for the development of a modest range of new constitutional review powers for the courts in the coming years.

\section{The traditional role of the courts: subordination to Parliament}

In the UK, there is no codified constitution setting out the role and powers of the judiciary. As a consequence, such powers have traditionally had to be inferred or induced from particular judicial decisions.

Historically, Britain's mixed model of government firmly subordinated the judiciary to the elected branches of government. The constitutional hierarchy, which stems from the doctrine of parliamentary sovereignty, conceived of the courts as subordinate to Parliament. Courts were to interpret the text and to declare the law, and they enjoyed only limited review powers over delegated authority by Parliament to subordinate bodies.
The impact of this subordination on the constitutional status of the courts has been enormous. Between 1842 and the UK's accession to the European Community in January 1973, not a single case reached the House of Lords on the question of the absence of limitations of Parliament's ultimate law-making authority. The period from World War II until the 1960s highlights the insignificance of the courts in developing the constitution.

\section{The Development of Powers of 'Quasi- Constitutional' Review}

Judicial expansion in the latter decades of the twentieth century have prompted a re-evaluation of the constitutional position of the judiciary. Over this period, the apex court gradually developed a public law profile, such that the United Kingdom Supreme Court (Supreme Court) can now be seen to discharge functions equivalent to those of a constitutional court.

Some of these new, 'quasiconstitutional' powers of the Supreme Court have been given to the court explicitly by Parliament. For example, the Supreme Court has been allocated powers of quasi-constitutional review under the European Communities Act
1972 (ECA), the Human Rights Act 1998 (HRA), and the UK's devolution legislation.

As regards the European Communities Act, Parliament's competence has been substantively limited in two ways: first, it may not legislate contrary to EU law; and second, courts enjoy power to 'disapply' national law to the extent that it is inconsistent with directly effective provisions of EU law. It is acting in this capacity that the Supreme Court most clearly discharges functions akin to the strong form judicial review exercised by constitutional courts elsewhere.

When courts review legislation under the HRA, the consequences are slightly different. That legislation permits courts to interpret primary legislation in order to achieve compliance with the Convention Rights, while providing for the issue of a declaration of incompatibility as an alternative. Though neither option permits the court to mount a direct challenge to the legality of an Act of Parliament, the HRA nonetheless empowers the courts to test legislation for compliance with human rights standards.

Under the Constitutional Reform Act 2005, the courts also have the power to determine legal disputes relating to 'devolution issues' arising out of the transfer of legal powers to devolved bodies, such as the Scottish Parliament, the Welsh National Assembly, or the Northern Ireland Assembly.

In addition to those powers of quasi-constitutional review allocated by statute, the expansion of the constitutional powers of the courts has occurred as a result of the decisions of judges themselves. At the 
most straightforward level, a judicial belief in the 'sanctity' of statutory language has yielded ground to more generous and purposive techniques of construction. Rather more fundamentally, the development of ideas associated with the 'common law constitution' - including the incremental development by the courts of a body of 'constitutional rights', and the creation of a distinction between constitutional and nonconstitutional statutes - have rendered our traditional understandings of the subordinate role of courts in relation to Parliament obsolete.

Indeed, in one significant case, Lord Hoffman went so far as to assert that the Supreme Court is now empowered to 'apply principles of constitutionality little different from those which exist in countries where the power of the legislature is expressly limited by a constitutional document.' Even if this is something of an overstatement, it is certainly true that unquestioning acceptance by the courts of legislative direction - however Draconian - may no longer be taken for granted under this new constitutional equilibrium.

\section{What powers of review should courts have?}

Any future determination of the respective constitutional role and function of the judiciary must then seek to address the tension between the sovereignty of Parliament and the rule of law by approaching them as equals, and should seek to make good the constitutional commitment to both democratic government and the rule of law.

In our view, it would be a step too far for the Supreme Court to assert the ability to strike down legislation. This would be a clear usurpation of the powers of the legislature. Instead, we see three legitimate judicial responses to Parliament doing the 'unthinkable' - for instance, passing legislation that disenfranchised a substantial proportion of the population on arbitrary grounds or insulated vast tranches of governmental activity from the scrutiny of the courts.

The most robust course available to the court is disobedience. In the exceptional case of a clash between constitutional fundamentals, the court may, for example, reinstate a jurisdiction apparently ousted by statute, or prevent the attempted insulation by statute of otherwise ultra vires activity from judicial review. This approach draws inspiration from the seminal decision in Anisminic $v$. Foreign Compensation Commission, as long ago as 1969. While falling short of US-style constitutional review, the possibility of this form of judicial disobedience to primary legislation remains the most potent weapon available to the Supreme Court in the event of a fundamental constitutional clash.

Sitting below outright disobedience, in legal terms at least, would be a judicial 'declaration of unconstitutionality.' Drawing inspiration from declarations of incompatibility under the HRA, David Jenkins has argued that the courts possess the inherent power to declare Acts of Parliament to be unconstitutional when Parliament legislates contrary to fundamental that are deemed by courts to be fundamental to the UK's unwritten constitution. Such declarations, Jenkins argues, would be respectful of sovereignty, because they would be not affect the formal legal validity of the statute in respect of which they were made.

The consequences of the issue of a 'declaration of unconstitutionality' would not be as severe as those of judicial disobedience. Such a declaration would in many cases be politically damaging, and could therefore provoke a legislative response. But there would be no requirement for Parliament to respond, the impugned statute would remain operable. The declaration of unconstitutionality would, therefore, better straddle the principle of judicial control and the principle of legislative supremacy, and offer greater respect to the political underpinnings of the UK constitution.

Finally, the courts may in certain constitutional cases need to soften the letter of the law through careful interpretation in order to achieve fairness in individual cases and to vindicate the judicial presumption that Parliament legislates 'for a European liberal democracy' in compliance with fundamental principles. Like equity, which mitigates the rigour of the common law, the rule of law ensures that the formal legal doctrine of Parliamentary sovereignty does not lose sight of constitutional principles that are of fundamental importance in individual circumstances.

In our view, a combination of these three options, used cautiously and in the appropriate context, would represent a legitimate and desirable development of the courts' constitutional powers. The courts share in the task of policing the boundaries of a rights-based democracy with the legislature and executive; their role is complementary to that of Parliament, and of the executive. To decry the quasi-constitutional functions of the courts as a step towards judicial supremacism is to deny the distinctive functions of the legislative and judicial branches. It also denies the crucial constitutional role of the courts in their habitual recognition of Parliament as sovereign. The constitutional functions and authority of the courts, therefore, form the embodiment of the balanced constitution in its modern incarnation.

Jo Murkens

(Department of Law, London School of Economics and Political Science

Roger Masterman

(Durham Law School, Durham University) 


\section{JO MURKENS}

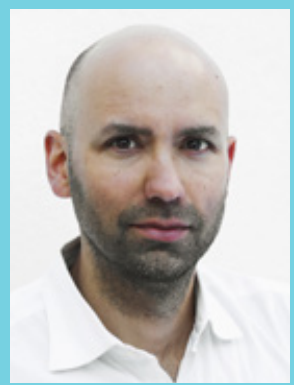

Jo Murkens is an Associate Professor of Law at the London School of Economics. He studied English and European Law in London and Copenhagen, and wrote his $\mathrm{PhD}$ at the European University Institute in Florence.

\section{ROGER MASTERMAN}

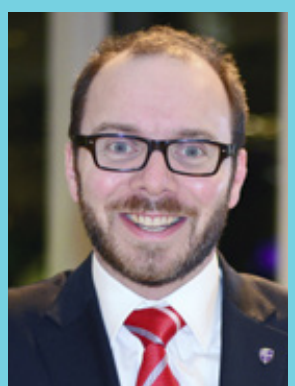

Roger Masterman is Professor of Law and Head of School at Durhma Law School. His teaching and research interests lie in constitutional law and reform - particularly in the Human Rights Act 1998 and in the doctrine of separation of powers.

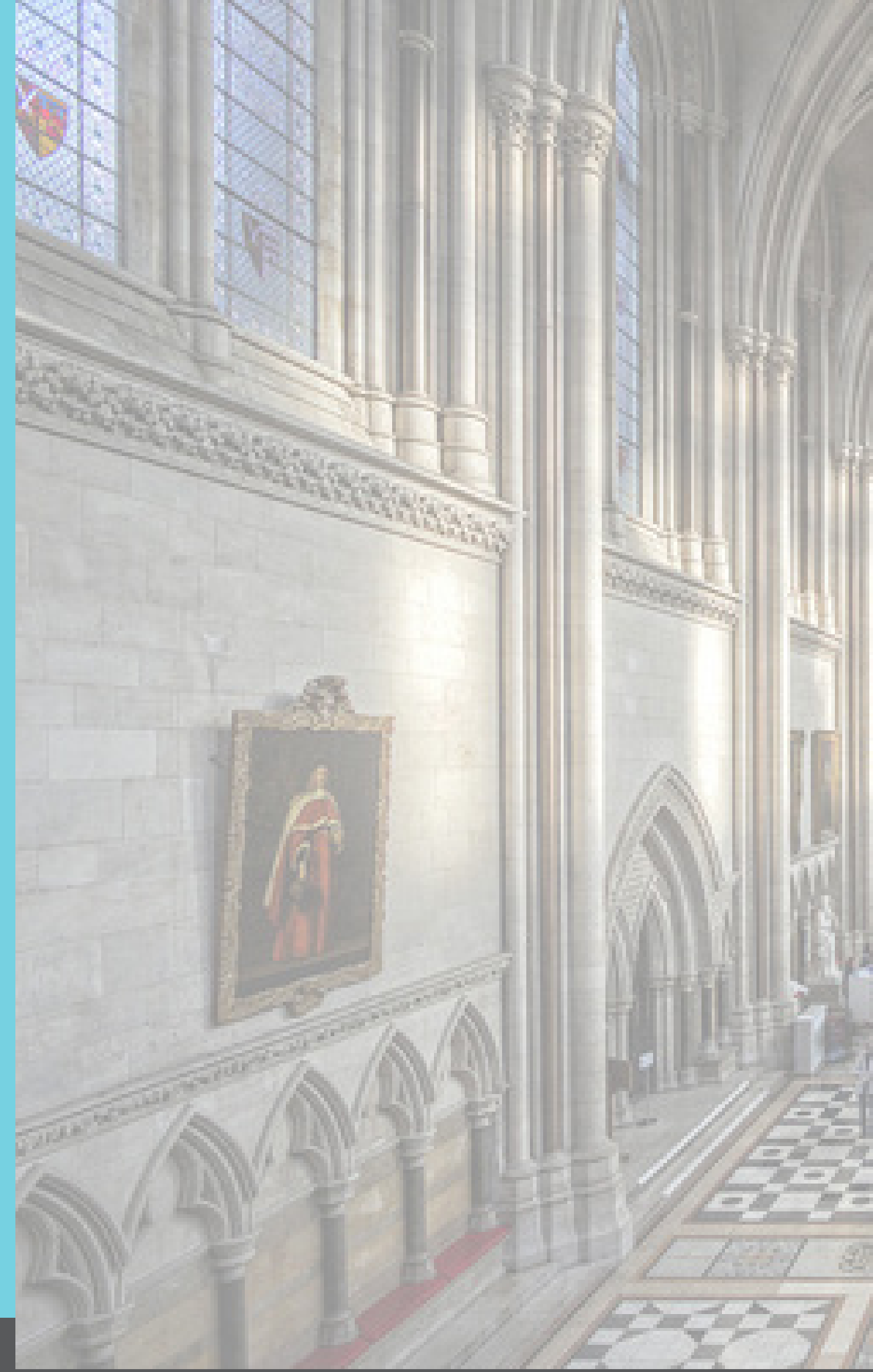

\section{LSE}

THE LONDON SCHOOL

OF ECONOMICS AND

POLITICAL SCIENCE

Department of Law

The London School of Economics

and Political Science

Houghton Street

London WC2A 2AE 